\title{
A ELEIÇÃO DIRETA DE DIRETOR ESCOLAR: DESAFIOS NA GESTÃO DEMOCRÁTICA NO MUNICÍPIO DE MEDICILÂNDIA - PARÁ
}

\author{
LA ELECCION DIRECTA DEL DIRECTOR DE LA ESCUELA: RETOS EN LA \\ GESTION DEMOCRATICA EN EL MUNICIPIO DE MEDICILÂNDIA - PARÁ
}

\author{
DIRECT ELECTION OF SCHOOL DIRECTOR: CHALLENGES IN DEMOCRATIC \\ MANAGEMENT IN THE MUNICIPALITY OF MEDICILÂNDIA - PARÁ
}

\author{
Marconde Ávila BANDEIRA ${ }^{1}$ \\ Ney Cristina MONTEIRO OLIVEIRA ${ }^{2}$ \\ Irlanda do Socorro de Oliveira MILÉO ${ }^{3}$
}

RESUMO: Este estudo aborda discussões sobre a gestão escolar e a eleição direta de diretores e sua relação com a democratização no processo de tomada de decisões, buscando refletir como se constitui o processo de eleição de diretor realizada na Escola Municipal de Ensino Fundamental Abraham Lincoln, que compõe a rede de ensino de Medicilândia-Pará, e em que medida esse mecanismo tem favorecido a participação da comunidade escolar e local nos processos decisórios da gestão escolar. Buscamos problematizar até que ponto o processo de eleição de diretor realizada na Escola Municipal de Ensino Fundamental Abraham Lincoln que compõe a rede de ensino de Medicilândia-Pará possibilita a organização do trabalho na escola na perspectiva da gestão democrática, e se esse mecanismo favorece a participação da comunidade escolar e local nos processos decisórios da gestão escolar. Como objetivo geral, analisa-se as percepções dos diversos sujeitos sociais presentes no espaço escolar sobre o processo de eleição direta para a escolha da direção escolar e sua possível relação com a gestão democrática na Escola Municipal de Ensino Fundamental Abraham Lincoln da rede municipal de Medicilândia-Pará. Por meio de uma pesquisa qualitativa com base em autores como Paro (2003; 2005; 2007; 2010), Luck (2008; 2009), Azevedo (2011), Cabral Neto (2009), Vieira (2007), Dourado (2007), nossos resultados demonstraram que nossos entrevistados possuem certa compreensão sobre o processo eleitoral direto para escolhas dos dirigentes escolar, e que esse mecanismo influencia significativamente para que ocorra uma gestão democrática escolar, uma vez que os participantes da pesquisa demostraram conhecimento sobre seu papel participativo no cotidiano da comunidade escolar e frequentemente participam da gestão escolar, que é compartilhada através dos conselhos, reuniões administrativas, reuniões de pais e mestres, construção e avaliação do PPP, reuniões e/ou oficinas sobre a organização do trabalho pedagógico. No que se refere à legislação municipal (Leis, Resoluções e PME), foi possível observar que as mesmas estão em consonância com o que expressa nossa LDB e nossa Constituição Federal de 1988, com

\footnotetext{
${ }^{1}$ Universidade Federal do Pará (UFPA), Belém - PA - Brasil. Mestrando Núcleo de Estudos Transdisciplinares em Educação Básica- Programa de Pós-graduação em Currículo e Gestão da Escola Básica. Pedagogo. ORCID: https://orcid.org/0000-0001-8414-0761.E-mail: bandeira.neto77@gmail.com

${ }^{2}$ Universidade Federal do Pará (UFPA), Belém - PA - Brasil. Professora Titular do Núcleo de Estudos Transdisciplinares em Educação Básica. Professora do Programa de Pós-graduação em Currículo e Gestão da Escola Básica. Doutorado em Educação (PUC/SP). ORCID: https://orcid.org/0000-0002-8091-5213. E-mail: neycmo@ufpa.br

${ }^{3}$ Universidade Federal do Pará (UFPA), Altamira - PA - Brasil. Professora Adjunta. Doutorado em Educação (PUC/SP). ORCID: https://orcid.org/0000-0002-7075-6503.E-mail: irlanda@ufpa.br
} 
dispositivos legais definidos, delineados, bem elaborados e com sua base alicerçada na gestão e organização do trabalho pedagógico macro através da Semed e micro por meio da gestão da unidade escolar na escola básica.

PALAVRAS-CHAVE: Gestão democrática. Eleição de diretor. Participação.

RESUMEN: Este estudio aborda las discusiones sobre la gestión escolar y la elección directa de los directores y su relación con la democratización en el proceso de toma de decisiones, buscando reflejar cómo el proceso de elección del director celebrado en la Escuela Primaria Municipal Abraham Lincoln, que compone la red de la escuela de medicina de Medicil-ndia-Pará, y en qué medida este mecanismo ha favorecido la participación de la escuela y la comunidad local en los procesos de toma de decisiones de la gestión escolar. Buscamos problematizar hasta qué punto el proceso de elección de director celebrado en la Escuela Primaria Municipal Abraham Lincoln que compone la red de educación medicilndia-pará permite la organización del trabajo en la escuela desde la perspectiva de la gestión democrática, y si este mecanismo favorece la participación de la escuela y la comunidad local en los procesos de toma de decisiones de la gestión escolar. Como objetivo general, analizamos las percepciones de los diversos temas sociales presentes en el espacio escolar sobre el proceso de selección directa para la elección de la dirección escolar y su posible relación con la gestión democrática en la Escuela Primaria Municipal Abraham Lincoln de la red municipal de Medicil-ndia-Pará. A través de una investigación cualitativa basada en autores como Paro (2003; 2005; 2007; 2010), Luck (2008; 2009), Azevedo (2011), Cabral Neto (2009), Vieira (2007), Dourado (2007), nuestros resultados demostraron que nuestros entrevistados tienen una cierta comprensión del proceso electoral directo para los líderes escolares, y que este mecanismo influye significativamente en el desarrollo de la gestión escolar democrática, ya que los participantes en la investigación demostraron conocimientos sobre su papel participativo en la vida diaria de la comunidad escolar y a menudo participan en la gestión escolar, que se comparte a través de consejos, reuniones administrativas, reuniones de padres y maestros, construcción y evaluación ppp, reuniones y/o talleres sobre la organización del trabajo pedagógico. Con respecto a la legislación municipal (Leyes, Resoluciones y Pymes), fue posible observar que están en línea con lo que nuestro LDB y nuestra Constitución Federal de 1988 expresan, con disposiciones legales definidas, delineadas, bien elaboradas y basadas en la gestión y organización del trabajo macro pedagógico a través de Semed y micro a través de la gestión de la unidad escolar en la escuela básica.

PALABRAS CLAVE: Gestión democrática. Elección del director. Participación.

ABSTRACT: This study approaches discussions on school management and the direct election of principals and their relation with democratization in the decision-making process, seeking to reflect how the process of election of principal held at the Abraham Lincoln Municipal Elementary School, which composes the teaching network of Medicilândia-Pará, and to what extent this mechanism has favored the participation of the school and local community in the decision-making processes of school management. We seek to problematize the extent to which the process of election of principal held at the Abraham Lincoln Municipal Elementary School that composes the medicilândia-pará education network enables the organization of work in the school from the perspective of democratic management, and whether this mechanism favors the participation of the school and local 
community in the decision-making processes of school management. As a general objective, we analyze the perceptions of the several social subjects present in the school space about the process of direct election for the choice of school direction and its possible relation with democratic management in the Abraham Lincoln Municipal Elementary School of the municipal network of Medicilândia-Pará. Through a qualitative research based on authors such as Paro (2003; 2005; 2007; 2010), Luck (2008; 2009), Azevedo (2011), Cabral Neto (2009), Vieira (2007), Dourado (2007), our results demonstrated that our interviewees have a certain understanding of the direct electoral process for school leaders' choices, and that this mechanism significantly influences the development of democratic school management, since the research participants demonstrated knowledge about their participatory role in the daily life of the school community and often participate in school management, which is shared through councils, administrative meetings, parent-teacher meetings, PPP construction and evaluation, meetings and/or workshops on the organization of pedagogical work. With regard to municipal legislation (Laws, Resolutions and SMEs), it was possible to observe that they are in line with what our LDB and our Federal Constitution of 1988 express, with legal defined devices, delineated, well elaborated and based on the management and organization of macro pedagogical work through Semed and micro through the management of the school unit in basic school.

KEYWORDS: Democratic management. Director's election. Participation.

\section{Introdução}

A discussão em torno da gestão educacional permanece posta em constante debate em nossa sociedade, em decorrência da movimentação de diferentes setores sociais que reivindicam maior participação na partilha das tomadas de decisão na elaboração e implementação das políticas no campo educacional, como condição da qualidade social da educação. Demandas essas fortalecidas no período da abertura política e do processo de redemocratização do Estado brasileiro vivenciados nas décadas de 1980 e 1990, por meio de mobilização que defendia a necessidade de descentralização e democratização das políticas sociais públicas (DOURADO, 2007; MILÉO, 2007; FERREIRA; AGUIAR, 2006).

Com as conquistas asseguradas pela promulgação da Constituição Federal de 1988, quando consagrou o princípio da "gestão democrática do ensino público" e a garantia da participação da sociedade civil nos conselhos gestores, e posteriormente com a aprovação da Lei de Diretrizes e Bases da Educação Nacional (LDB) - Lei nº 9394/1996, que criou expectativas e condições legais quanto ao fortalecimento da autonomia da gestão das instituições escolares como mecanismos para a construção desse espaço democrático, por meio da participação da comunidade escolar e local nos dos conselhos escolares, segundo apontam Paro (2005) e Luck (2008), como importante canal participativo na democratização 
do ensino público, por ter sido celebrado "[...] como base fundamental para a organização significativa e estabelecimento de unidade dos processos educacionais e mobilização das pessoas voltadas para o desenvolvimento e melhoria da qualidade do ensino que oferecem" (LUCK, 2008, p. 33).

Contudo, diferentes estudos realizados por pesquisadores da área (CABRAL NETO, 2009; PARO, 2007; VIEIRA, 2007) têm apontado entraves de ordem sociocultural e política, ao destacarem que a consolidação da gestão democrática não se sustenta somente a partir das questões legais, pois a gestão educacional e escolar está alicerçada em ações humanas e demandam condições materiais e imateriais. Embora considerada de extrema importância para garantir o direito à participação e ao exercício da cidadania, os autores enfatizam que em virtude da totalidade de relações que se materializam no interior das instituições em geral, a gestão educacional sofre interferências dos mais diversos setores que possuem interesses nem sempre consensuais aos princípios democráticos, consubstanciando-se em práticas resultantes das características conservadoras e de uma tradição de autoritarismo, ainda presentes na realidade brasileira, que podem vir a distorcer o seu significado.

Temas como a participação social, democratização do ensino, eleição de diretores das instituições de ensino despontaram como elementos de um movimento em defesa de processos democráticos institucionais e dos serviços públicos que podem impulsionar o compartilhamento nas tomadas de decisões quanto aos rumos da educação. A partir do exposto, aponta-se neste estudo a eleição do diretor escolar como mecanismo que permite revelar as concepções democráticas de gestão escolar e possíveis aproximações ou distanciamentos no que diz respeito à democratização das tomadas de decisões no âmbito administrativo e pedagógico das escolas (PARO, 2003), por esse profissional ser o responsável em liderar a construção e a execução do projeto pedagógico, bem como, em organizar o funcionamento da escola e em interagir com os vários sujeitos que ali se encontram.

Nessa perspectiva, problematizamos a seguinte questão: Como se constitui o processo de eleição de diretor realizada na Escola Municipal de Ensino Fundamental Abraham Lincoln, que compõe a rede de ensino de Medicilândia-Pará? Em que medida esse mecanismo tem favorecido a participação da comunidade escolar e local nos processos decisórios da gestão escolar?

Como objetivo geral, analisamos as percepções dos diversos sujeitos sociais presentes no espaço escolar sobre o processo de eleição direta para a escolha da direção escolar na Escola Municipal de Ensino Fundamental Abraham Lincoln da rede municipal de 
Medicilândia-Pará. Como objetivos específicos, buscamos examinar as bases legais que fundamentam a eleição da gestão escolar em Medicilândia; identificar as concepções dos diferentes atores sociais presentes no âmbito escolar sobre gestão democrática; verificar a partir dos posicionamentos dos entrevistados, como a direção escolar influencia a organização do trabalho na escola na perspectiva da gestão democrática na escola investigada.

Este estudo orienta-se a partir da pesquisa qualitativa por meio de um estudo de caso exploratório na Escola Municipal de Ensino Fundamental Abraham Lincoln, que segundo Yin (2010), "é usado em muitas instituições, para contribuir ao nosso conhecimento dos fenômenos individuais, grupais, organizacionais, sociais, políticos e relacionados".

A pesquisa contou inicialmente com uma revisão da literatura pertinente ao tema abordado, fundamentando-se em autores como Paro (2003; 2005; 2007; 2010), Luck (2008; 2009), Cabral Neto (2009), Vieira (2007), Dourado (2007), Azevedo (2011). Em relação aos documentos que tratam sobre a gestão democrática, analisamos a Constituição Federal de 1988, a LDB 9394/96, o Regimento Escolar - Resolução nº 085, de 31 de janeiro de 2011; Lei Complementar $n^{\circ}$ 001/2015, que dispõe sobre a reformulação do Plano de Cargos, Carreiras e Remuneração dos Profissionais em Educação Básica do ensino público da rede municipal de Medicilândia e de sua gestão; Lei no 430/2015 que aprova o Plano Municipal de Educação. Estes documentos orientaram a sistematização quanto à normatização e compreensão das concepções sobre participação, gestão democrática e o processo de eleição da direção escolar.

Como técnica de pesquisa, adotamos entrevistas semi-estruturadas, que foram realizadas com 6 docentes, sendo que duas professoras entrevistadas são conselheiras, uma presidente do Conselho Escolar e a outra é secretária. Entrevistamos ainda os representantes da atual gestão escolar (2016-2018), a diretora e a coordenadora pedagógica; dois estudantes do $9^{\circ}$ ano do Ensino Fundamental, e dois Secretários Municipais de Educação - período de 2001-2004 e o atual (2017-2020).

O artigo está estruturado em três seções. Na primeira seção abordamos as discussões referentes ao contexto sociopolítico que marcou o debate no cenário brasileiro sobre a gestão da educação; na segunda seção trazemos reflexões sobre o marco legal/institucional sobre a gestão democrática como princípio na Constituição Federal de 1988 e na LDB 9394/96, bem como as dimensões que possibilitam sua efetivação no espaço escolar, dando destaque aos conselhos escolares e ao processo de eleição direta à direção escolar. Na última parte, apresentamos os dados do estudo de caso realizado na EMEF Abraham Lincoln da rede municipal de Medicilândia-Pará, a partir dos relatos dos sujeitos participantes da pesquisa. 


\section{A gestão da educação no contexto brasileiro: possibilidades e desafios}

No Brasil, o debate sobre o conceito de administração escolar e da administração da educação, particularmente no período de transição da década de 1980, apresentava-se fortemente marcado pelo contexto político-ideológico da época. Como destaca Azevedo (2011), suas raízes histórico-teóricas assentam-se no cerne das ciências da administração, sobrevindas dos pressupostos de Taylor e Fayol, como parâmetro dos processos produtivos nas sociedades industriais, tendo sido mais tarde aprimorados pelo fordismo. Enaltecido pelo projeto modernizante do regime burocrático-autoritário dos governos militares (1964-1985), a disseminação da racionalidade técnico-científica passou a nortear o projeto de desenvolvimento implantado na sociedade brasileira e, por consequência, tornou-se o principal instrumento do planejamento das políticas públicas, tendo todos os controles/regulação centralizados na esfera federal.

Vitor Paro destaca (2010) que esse modelo de administração escolar caracterizava-se por medidas racionais, técnicas e mecânicas dos recursos e das atividades-meio e atividadesfim, ou seja, ações que envolvem diretamente o processo ensino-aprendizado, ao separar o planejamento da execução, reforçados pela lógica técnico-burocrática. O autor considera que o caráter administrativo da educação busca a "utilização racional de recursos para a realização de fins determinados" (PARO, 2010, p. 18), no sentido de normatizar pragmaticamente a consecução dos objetivos educativos da instituição escolar; em relação ao âmbito das instituições escolares, o objeto da ação administrativa operacional nas “[...] práticas escolares realizadas com o propósito de buscar racionalmente o objetivo pedagógico" (PARO, 2010, p. 72).

De acordo com Luck (2008), a gestão da educação a partir dos anos de 1980 supera o enfoque limitado de administração ao considerar que a problemática educacional é complexa e demanda um foco globalizado e contínuo, com atuação articulada, dinâmica e participativa. A autora argumenta que a política de gestão democrática do ensino avança quando traz consigo a dimensão da participação nos processos decisórios, como estratégia mobilizadora das equipes de trabalho coletivamente organizados, centralizando forças nos direcionamentos das políticas de ensino e de seus sistemas a partir da defesa de uma educação de qualidade. Assim,

O conceito de gestão resulta de um novo entendimento a respeito da condução dos destinos das organizações, que leva em consideração o todo em relação com as suas partes e destas entre si, de modo a promover maior 
efetividade do conjunto. A gestão aparece, pois, como superação das limitações do conceito de administração, como resultado de uma mudança de paradigma (LUCK, 2008, p. 34).

Ao tratar sobre o conceito de "Gestão", é preciso entender o significado de termos que estão interligados, mas que guardam em si aspectos que precisam ser considerados quanto às competências e atribuições. Quando nos referimos à Gestão Educacional, esta se situa no nível macro da Educação, ou seja, ao âmbito dos sistemas educacionais federal, estadual e municipal em articulação com órgãos superiores dos sistemas de ensino brasileiro, e respondem pelas orientações e definições gerais que regulamentam as políticas educativas, como também, pelo planejamento, o acompanhamento e a avaliação. Em relação à Gestão Escolar, sua esfera de abrangência estabelece-se em nível micro, isto é, nas instituições escolares, e tem como principal atribuição a elaboração da proposta pedagógica, bem como, administrar seu pessoal, seus recursos materiais e financeiros. Segundo Vieira (2007):

A gestão educacional refere-se a um amplo espectro de iniciativas desenvolvidas pelas diferentes instâncias de governo, seja em termos de responsabilidades compartilhadas na oferta de ensino, ou de outras ações que desenvolvem em suas áreas específicas de atuação. A gestão escolar, por sua vez, como a própria expressão sugere, situa-se no plano da escola e diz respeito a tarefas que estão sob sua esfera de abrangência (VIEIRA, 2007, p. $64)$.

Porém, ao debatermos temas referentes à gestão da educação, precisamos considerar as transformações sociopolíticas decorrentes de um movimento reformista nas últimas décadas no contexto brasileiro, no que diz respeito à elaboração de políticas públicas promovidas pelo Estado, enquanto instituição responsável pela organização dos diferentes setores sociais. Tais mudanças resultam em um conjunto de determinações institucionais com objetivos de implementar reformas que alteram expressivamente a legislação, a administração pública e estrutura do governo central, de modo a proporcionar maior governabilidade ao Estado (CABRAL NETO, 2009).

Essas mudanças decorrem de um movimento mundial ocasionado pelas macros e micros tendências das relações produtivas decorrentes de um processo complexo de reestruturação econômica globalizada assentada no modelo neoliberalista, podendo ser percebidas no conjunto espesso das modificações econômicas, políticas, culturais e geográficas, caracterizando o mundo da atualidade. As reformas das ações estatais operacionalizadas nos diferentes Estados-Nação nos últimos anos interferem direta e indiretamente nas políticas educativas, na concepção de escola e na organização do trabalho pedagógico, segundo destaca Libâneo (2012). Em suas análises sobre o neoliberalismo, o 
autor aponta que essas ações reformistas apresentam algumas linhas constitutivas, que são "mudanças nos processos de produção associadas a avanços científicos e tecnológicos, superioridade do livre funcionamento e redução do papel do Estado" (LIBÂNEO, 2012, p. 42).

Nessa direção, se na década de 1980, a agenda defendida no cenário educacional brasileiro se deu a partir de um movimento em favor da gestão democrática do ensino público e de garantia do seu padrão de qualidade via o estabelecimento de marco legal que garantisse o exercício de práticas democráticas e o controle social das ações estatais via a participação popular nos espaços públicos, por meio da eleição para diretores e da implantação dos conselhos escolares como estratégias de inovação ou panacéia para o campo educativo (PARO, 2003). A década de 1990, por sua vez, foi marcada pelo processo de modernização do aparelho estatal brasileiro, que ajustou seu perfil e suas competências ao novo modelo de Estado Regulador por meio do Plano Diretor da Reforma do Estado (PDRAE, 1995), mediante a adoção do gerencialismo ou da nova gestão pública (new public management), que segundo Miléo (2007, p. 70):

Trata-se de uma reforma assentada em três dimensões: a institucional - que é responsável pelas transformações das instituições normativas e fundamentais; a cultural - que implica em mudança na forma de pensar os serviços sociais; e a gestão - fundamentada na gestão da qualidade total, modelo desenvolvido pelo setor privado, figura como estratégia básica do governo na busca da excelência da administração da coisa pública.

Com a reestruturação do Estado, o governo brasileiro afirma os princípios neoliberais a partir do estreitamento da relação entre educação e desenvolvimento econômico, em consonância às orientações de organismos internacionais como a Organização das Nações Unidas para a Educação, a Ciência e a Cultura (UNESCO), Banco Mundial, Banco Interamericano de Desenvolvimento, dentre outros ${ }^{4}$. Tais modificações assumidas implicaram em transformações complexas e não lineares tanto no nível do sistema educacional, quanto nos outros setores sociais, dirigidas por diferentes forças políticas e governos, observando-se nos últimos anos, avanços e de recuos que implicam diretamente na gestão educacional e escolar, em decorrência de um conjunto de diretrizes e linhas de ações assentadas em uma racionalidade instrumental de produtividade e competitividade ocultada pelo discurso da qualidade e da excelência como prerrogativa de tornar o País mais competitivo em um mundo globalizado. Ao analisar essa questão, Azevedo (2011) considera que,

${ }^{4}$ Para uma maior compreensão sobre as implicações da reforma do Estado no campo das políticas educacionais, consultar Castro Neto (2009); Azevedo (2011). 
Segundo os princípios que regeram a reforma administrativa do Estado brasileiro, buscou-se, com o gerencialismo, dentre outros aspectos, um envolvimento direto da comunidade com os processos das decisões escolares, defendendo-se, também, o princípio da participação, tal como na perspectiva da gestão democrática. Porém, por meio de um processo restrito e controlado, visto que o núcleo duro das decisões permaneceu privilégio de uns poucos, em geral adstrito ao poder central (AZEVEDO, 2011, p. 420).

Nessa direção, a gestão da educação escolar passa por alterações resultantes do processo de desestatização do setor público viabilizada pela transferência de recursos e atribuições para os governos estaduais e municipais via a descentralização política e administrativa; pela racionalização dos investimentos e centralização dos processos decisórios em relação à elaboração e implementação das políticas educacionais, não contribuindo em nada para a democratização da educação, como destaca Azevedo (2011). Ao contrário, verificamos a contradição quanto ao ideário democrático na década seguinte, visto que estes sofrem ofensivas diante da implantação de políticas educacionais orientadas pelo gerencialismo, que conferem aos resultados do processo de escolarização a suposta ineficiência, sobretudo da gestão dos sistemas e das escolas, ou seja, a gestão ganhou uma abordagem vinculada aos referenciais específicos da corrente neoliberal da educação. Porém, essas ofensivas contra as ações educativas democráticas não conseguiram suplantar o ideário da gestão fundamentada no princípio da democracia nos espaços escolares, aspectos que serão discutidos a seguir.

\section{Os princípios da gestão democrática e os mecanismos de provimento do cargo de diretor escolar}

Abordar discussões referentes à gestão democrática implica compreender o redimensionamento da função sociocultural do fazer escolar que transcende o espaço institucional, trazendo em si diferentes entendimentos e percepções que ora confluem, ora dispersam as ações participativas e os processos decisórios, por estas serem materializadas pelos agentes educativos que atuam na escola e nos demais órgãos dirigentes. Destarte, o conceito de gestão democrática articula-se à defesa da qualidade da educação, considerando o processo de universalização do ensino, bem como aos fundamentos da gratuidade, permanência e terminalidade (PARO, 2003; CURY, 2005).

Como discutido, a institucionalização da gestão democrática no Brasil foi assinalada por um período de mudanças políticas, econômicas, sociais; mas igualmente, por lutas populares e reformas. Para Luck (2008), toda essa dinâmica resultou no estabelecimento de 
marcos legais/institucionais, conquistas e contradições, uma vez que contribuiu para reforçar o enfrentamento às forças autoritárias e centralizadoras ainda presentes nas secretarias estaduais e municipais de educação, quando instituem uma correlação desigual de forças com as escolas em relação aos processos decisórios.

Por outro lado, a gestão democrática precisa ser compreendida como mais um ato político e menos como uma ação administrativa e burocrática, pois como enfatiza Paro (2005), a gestão democrática alude à concretização de novos processos de organização e gestão alicerçados em uma relação conjunta que oportuniza a construção de processos participativos e partilha do poder de decisão.

Assim, garantida na Constituição Federal de 1988, no artigo 206, Inciso IV, a “[...] gestão democrática do ensino público, na forma da lei”, representa um princípio constitucional que fortalece a educação como um direito de todos, ao mesmo tempo que exprime a ideia de participação e de uma cultura democrática na esfera do ensino público.

Esse princípio é afirmado na década de 1990, mediante a aprovação da LDB - Lei 9.394/96, quando dispõe sobre a "gestão democrática do ensino público, na forma da Lei e da legislação dos sistemas de ensino" (Art. $3^{\circ}$, Inc. VIII). A LDB avança ao preceituar as estratégias e dimensões que as instituições escolares podem adotar para implementar a gestão democrática. De acordo com Vieira (2007, p. 62), como dimensão desse modelo de gestão, essa Lei preconiza no seu art. 12 o estreitamento da relação entre a escola e a sociedade, devendo esta "articular-se com as famílias e a comunidade, criando processos de integração", tendo também a responsabilidade de "informar os pais e responsáveis sobre a frequiência e o rendimento dos alunos, bem como sobre a execução de sua proposta pedagógica" (Inc. VI e VII).

Outro aspecto a ser destacado é o detalhamento que a LDB faz em relação à necessidade de leis complementares no âmbito dos sistemas de ensino, para assegurar a gestão democrática, conforme expressa o caput do art. 14.

Art. 14. Os sistemas de ensino definirão as normas da gestão democrática do ensino público na educação básica, de acordo com as peculiaridades e conforme os seguintes princípios:

I - participação dos profissionais da educação na elaboração do projeto pedagógico da escola;

II - participação das comunidades escolar e local em conselhos escolares ou equivalentes (BRASIL, 1996).

Com a prerrogativa de repensar os rumos da educação no País, foi aprovado o Plano Nacional de Educação (PNE) - Lei n. 10.172, de 9 de janeiro de 2001, com a proposta de 
possibilitar ações que envolvessem a participação da sociedade e de todos os agentes educativos da comunidade escolar, tendo como uma de suas metas a criação de Conselhos Escolares em estabelecimentos oficiais da educação básica, visando alcançar impactos expressivos na melhoria da qualidade do processo ensino-aprendizagem. Todavia, este PNE não obteve o êxito previsto, visto que "em verdade, os planos de educação tendem a pecar por dois problemas: de um lado, o excesso de propostas; de outro, a falta de previsão orçamentária” (VIEIRA, 2007, p. 60).

No ano de 2014, foi aprovado o PNE - Lei $n^{\circ}$. 13.005, que na Meta 19 estabelece o prazo de 2 anos após sua aprovação, para garantir condições de "efetivação da gestão democrática da educação, associada a critérios técnicos de mérito e desempenho e à consulta pública à comunidade escolar, no âmbito das escolas públicas, prevendo recursos e apoio técnico da União para tanto" (BRASIL, 2014). Nessa assertiva, a gestão democrática mesmo amparada na legislação ainda implica em desafios no contexto escolar, pois expressa novos processos de organização do trabalho escolar fundamentados em uma dinâmica que propicie processos coletivos e participativos de decisão (PARO, 2005).

Segundo Paro (2007), ao tratar especificamente da gestão democráticas no âmbito das instituições de ensino, argumenta a necessidade de lançar mão de medidas que oportunizem participação dos usuários da escola quanto aos processos decisórios sobre as ações socioculturais da escola pública e que são reunidas em três tipos: aquelas pautadas nos canais coletivos de participação - o conselho de escola, associação de pais e mestres - sendo estes espaços para deliberações coletivas fortalecendo o controle social nas unidades escolares; a eleição direta para a escolha dos dirigentes escolares - permitindo à comunidade participar diretamente do processo eleitoral; e aquelas que se situam no âmbito de outras iniciativas participativas e no envolvimento de alunos, professores e pais nas atividades escolares.

Quando falamos em democratização da educação, precisamos considerar que os processos de sua organização e gestão se articulam aos diferentes graus de autonomia existentes nos sistemas escolares mediante a efetiva participação dos seus segmentos nos processos decisórios, buscando assegurar a existência de "progressivos graus de autonomia pedagógica e administrativa e de gestão financeira" (LDB, Art. 15). Autonomia que norteia a construção da identidade e história da instituição escolar, a sua própria forma de existir (AZEVEDO, 2011; VIEIRA, 2007).

De acordo com Luck (2006), a autonomia é o conceito mais citado nos sistemas de gestão de ensino, nos programas do Ministério da Educação, constituindo condição para efetivação dos princípios constitucionais e da legislação educacional, posto que a autonomia 
da gestão escolar, com os recursos de controle local, com a liderança da direção, participação comunitária e organização do trabalho pedagógico é considerada pilar essencial à democratização da educação.

É inegável que essas proposições decorrentes das legislações no contexto da gestão escolar proporcionaram modificações acerca do papel da comunidade escolar, porém, precisam ser efetivadas de fato, como é o caso dos Conselhos Escolares, em que na atualidade ainda se observa uma participação limitada, conforme analisa Aguiar (2008). Segundo destaca a autora, mesmo com a aprovação da Portaria Ministerial n. 2.896/2004, que instituiu o Programa Nacional de Fortalecimento dos Conselhos Escolares nas escolas públicas de educação básica, nota-se um escasso comparecimento de pais e mães nas reuniões convocadas e nas decisões aprovadas, pois essas são frequentemente para reiterar medidas já adotadas ou previamente decididas pelos docentes e equipe técnico-pedagógica da escola; ou aquelas determinações que a direção escolar precisa implantar, por definições precedentes da secretaria municipal ou estadual.

Conforme Luck (2006), órgão colegiado é instrumento de gestão escolar com objetivo de partilhar as decisões no coletivo, com participação interacional da comunidade escolar, significando compromisso da sociedade na vida cotidiana escolar. Esse compromisso participativo poderá ocorrer de diversas formas, conforme deliberação do conselho, como por meio de atividades para elaboração, monitoramento e avaliação do projeto político pedagógico; envolvimentos em atividades pedagógicos da escola; participação em rodas de conversas de pais, com intuito de discutir as trajetórias em relação à educação dos filhos; apoiar ações de desenvolvimento do trabalho pedagógico da escola; dentre outras.

Isso significa dizer que a organização da escola em uma perspectiva democrática precisa pautar-se em princípios de solidariedade, de participação coletiva, e de partilha de poder; aspectos que pressupõem uma gestão compartilhada, no sentido de superar práticas centralizadoras e de tendências de controle hierárquico tradicional, estimulando maior envolvimento e compromisso de todos os sujeitos preocupados com o processo decisório da escola. Paro (2005) considera que pais, alunos, professores e demais funcionários precisam participar na tomada de decisões desde a etapa inicial do planejamento pedagógico até a fase de implementação e avaliação das práticas escolares.

Outra estratégia que contribui para o aperfeiçoamento da gestão democrática é a escolha para provimento do cargo de direção escolar, como enfatiza Luck (2006), que deve ser eleito pela comunidade escolar, rompendo com o modelo impositivo pelos políticos. Entretanto, essas iniciativas não foram disseminadas em todas as escolas brasileiras, e a 
eleição direta, dependendo da forma como é efetivada, não significa sinal de democratização da política de gestão das unidades escolares envolvidas.

Para Gadotti e Romão (2006), essa escolha pode ocorrer pela nomeação, o concurso público, a eleição direta, ou ainda, pela adoção do esquema misto. Segundo os autores, a nomeação ocorre mediante a prática da indicação do diretor como cargo de confiança por uma pessoa externa à escola; na maioria das vezes, essa indicação é realizada pelo gestor municipal ou governador. Gadotti e Romão (2006) consideram que essa forma de escolha não oferece segurança para a gestão democrática e para o profissional, pois, ao se tratar de indicação alicerçada muito mais em critérios político-clientelistas que técnico-acadêmicos, esse profissional está ligado aos interesses de quem indicou, podendo ser substituído a qualquer momento, comprometendo as práticas gestionárias.

O posicionamento de Paro (2003) se aproxima da compreensão evidenciada por Gadotti e Romão (2004), pois considera que o principal problema que decorre dessa prática de escolha da direção escolar sem critérios democráticos é o favorecimento dos interesses particulares do executivo local ou das forças políticas responsáveis pela nomeação em detrimento à garantia dos interesses da comunidade escolar e local, da qual é subtraído o direito a exercer sua cidadania.

Segundo observa Paro (2003), essa forma de ocupação do cargo de direção escolar predominava até a promulgação da Constituição de 1988, cuja justificativa para sua manutenção assentava-se na prerrogativa da democracia representativa, ou seja, se o executivo local era eleito pela sociedade para definir questões e demandas dos diferentes segmentos sociais, portanto, essas nomeações teriam legitimidade e evitariam conflitos na administração. Contudo, esse procedimento em nada democrático permanece até os dias atuais na grande maioria dos municípios brasileiros, trazendo riscos para a efetivação da democracia nas unidades escolares, alimentando as gestões autoritárias, fisiologistas e nepotistas.

Em relação ao concurso público, este pode ser realizado por meio de prova ou de provas e títulos, que tem por finalidade aferir o grau de conhecimento técnico e a constatação da formação acadêmica adequada para o exercício das funções próprias do cargo de diretor escolar. De acordo Gadotti e Romão (2004), se por um lado essa forma de escolha pode apresentar condições objetivas para o efetivo exercício do cargo, como a competência profissional e a redução do nepotismo e clientelismo, há críticas por parte da comunidade escolar em relação a esse mecanismo. Embora o concurso defina critérios objetivos e técnicos, esse não consegue avaliar a capacidade de liderança dos candidatos ao cargo e, ainda, tira a 
possibilidade de a comunidade participar do processo de eleição da direção escolar. Assim, “o concurso acaba sendo democrático para o candidato, que, se aprovado, pode escolher a escola onde irá atuar, mas é antidemocrático em relação à vontade da comunidade escolar, que é obrigada a aceitar a escolha do primeiro" (GADOTTI; ROMÃO, 2004, p. 94).

No que diz respeito à eleição direta para o provimento do cargo da direção, Paro (2003) considera esse mecanismo o mais próximo para a garantia do exercício de gestão democrática da unidade escolar e colegiada por possibilitar diálogo no espaço escolar, bem como o envolvimento da comunidade local e escolar na distribuição do poder decisório, cumprindo também a perspectiva das competências técnica e política necessárias ao exercício da gestão escolar. Pode ser realizada de diferentes maneiras: por meio do voto direto, representativo, uninominal ou a partir das escolhas via listas tríplices ou plurinominais. Por isso o autor considera favorável esse mecanismo visto sua "a relevância de se considerar a eleição direta, por parte do pessoal escolar, alunos e comunidade, como um dos critérios para a escolha do diretor de escola pública" (GADOTTI; ROMÃO, 2004, p. 26-27).

Quanto ao esquema misto de eleição, este combina duas ou mais etapas no processo de seleção dos diretores. Segundo apontam Gadotti e Romão (2004), essas etapas podem se composta de provas para conferir a formação e competência técnica dos candidatos, e eleições para verificar sua experiência na área administrativa da educação, habilidade de liderança, dentre outros aspectos. Por meio da adoção desse esquema misto, há possibilidades de a comunidade escolar participar de uma ou mais etapas do processo seletivo, garantindo maior interação e compromisso entre a direção escolhida e os usuários da instituição escolar.

Como é possível percebermos, nos dispositivos legais brasileiros estão descritas as normas a serem executadas pelos gestores públicos nos diversos níveis do Poder Público no campo da gestão da educação; entretanto, concordamos com Vieira (2007) quando diz que falta muito a avançar em termos de estreitar a comunicação entre os profissionais que atuam no âmbito das secretarias de educação e das instituições escolares, dos órgãos normativos dos sistemas de ensino ou outras instituições que constituem o sistema educacional, nos diversos níveis do Poder Público.

\section{O contexto investigado: a eleição da gestão escolar no município de Medicilândia}

A temática abordada neste estudo apresenta uma especificidade diferenciada por tratar-se de uma prática que ainda não é muito comum nas escolas brasileiras. O processo de eleição direta para o cargo de direção escolar como mecanismo de gestão democrática, 
embora apresente respaldo legal na CF/1988 e na LDB 9394/96, não é uma prática comum nos municípios brasileiros, imperando ainda a modalidade da indicação do executivo local na escolha para o exercício para esse cargo, como atestam Paro (2003) e Gadotti e Romão (2004).

Nessa assertiva, a metodologia que sustenta nossas reflexões fundamenta-se na pesquisa qualitativa, por essa abordagem explicar a particularidade do objeto de estudo, possibilitando a interpretação dos fenômenos sociais encontrados no locu investigado. De acordo Minayo (2010, p. 21), a pesquisa qualitativa se ocupa no campo das Ciências Sociais “[...]com um nível de realidade que não pode ou não deveria ser quantificado. Ou seja, ela trabalha com o universo dos significados, dos motivos, das aspirações, das crenças, dos valores e das atitudes [...]".

Como estratégia de pesquisa, optamos pelo estudo de caso exploratório, por este possibilitar um estudo da particularidade e da complexidade de um dado contexto, o que leva a entender sua atividade dentro de importantes circunstâncias. Para Yin (2010), estudo de caso refere-se a uma investigação empírica que objetiva estudar um fenômeno com profundidade, envolvendo aspectos referentes ao planejamento, técnicas de coleta de dados e análise dos mesmos, cuja finalidade é permitir uma familiarização sobre um assunto que será abordado, no sentido de oportunizar a delimitação da temática e de seus objetivos a serem estudados posteriormente, tornando o problema mais explícito.

Ludke e André (1986) entendem o estudo de caso como uma metodologia que tem o objetivo de estudar a partir de um enfoque que abrange as complexidades dos fenômenos em suas interconexões com a realidade e com os sujeitos que dela fazem parte. Assim, o pesquisador busca “[...] revelar a multiplicidade de dimensões presentes numa determinada situação ou problema, focalizando-o como um todo. Esse tipo de abordagem enfatiza a complexidade natural das situações, evidenciando a inter-relação dos seus componentes" (LUDKE E ANDRÉ, 1986, p. 19).

Para Yin (2010), o pesquisador precisa se apropriar da complexidade e dinamismo inerente a esse tipo de pesquisa, de modo a permitir ao leitor a compreensão e construção de novos conhecimentos. Para isso, destaca três estratégias gerais que orientam a análise das evidências coletadas no estudo de caso. A primeira refere-se às proposições teóricas conexas ao objeto investigado, que fundamentam os objetivos, as questões da pesquisa, a literatura acerca da temática abordada e as conjecturas que possam emergir no decorrer das investigações. A segunda estratégia analítica articula-se às explicações concorrentes que ajudam o pesquisador a fazer avaliações do caso estudado. Por último, o autor destaca a 
descrição de caso, sendo esta responsável pela organização da estrutura descritiva a fim de organizar o estudo de caso, sendo considerada atividade indispensável quando o pesquisador enfrentar dificuldades em empregar as proposições teóricas ou explicações concorrentes.

A coleta de dados foi realizada com apoio da equipe de gestão escolar, a partir da realização de entrevistas semiestruturadas com a direção e coordenação pedagógica atual; seis docentes, sendo duas professoras membros do conselho escolar; dois alunos do $9^{\circ}$ ano do Ensino Fundamental; e ainda, dois Secretários de Municipais de Educação, a respeito do espaço e as rotinas escolares, das ações da gestão escolar a fim de identificar as impressões, os desafios, possibilidades, bem como acerca das contribuições das experiências adquiridas sobre a gestão democrática por meio do processo de eleição direta para o cargo da direção da escola.

A pesquisa de campo na unidade escolar ocorreu nos meses de maio e de junho de 2018, junto à Escola Municipal de Educação Ensino Fundamental (EMEF) Abraham Lincoln, com código no MEC n. 15106829, localizada no perímetro urbano do município de Medicilândia, estado do Pará.

Conforme Torres (2015), a referida escola ganhou essa denominação por causa da fundação do projeto "Agroindustrial e Canavieiro da Usina de Açúcar Abraham Lincoln”, nome dado pelos militares com a finalidade de homenagear o presidente norte-americano. A escola foi fundada entre 1971 e 1972, no processo de colonização da Transamazônica pelo então governo Médici que, de início, ofertava as séries iniciais do ensino fundamental menor, ficando o governo estadual com a incumbência de administrá-la, com auxílio do governo federal, por essa localidade fazer parte do projeto de colonização na época. Mais tarde, em 1978, com a chegada das irmãs franciscanas vindas do sul do Brasil, estas foram responsáveis pela primeira direção escolar local, e implantaram o ensino fundamental maior, se tornando escola sede do município.

Torres (2015) situa que o primeiro prédio dessa unidade escolar era uma estrutura de madeira distribuída em salas de aulas e um barracão comunitário; no ano de 1985, a comunidade local conseguiu uma estrutura física mais adequada de alvenaria, após se organizarem em comitiva e se descolarem até Brasília, com intuito de reivindicar recursos financeiros para a manutenção da escola, propondo que a mão de obra para a construção da escola seria a contrapartida dos moradores da localidade. O reconhecimento da EMEF Abraham Lincoln junto ao Conselho Estadual de Educação (CEE) ocorreu somente em 14 de setembro de 1989, por meio da Resolução n. 322/1989/CEE. A gestão escolar foi de responsabilidade do governo estadual até 1997, pois, em decorrência do processo de 
municipalização do ensino implantado no estado do Pará ${ }^{5}$, passou a ser gerida pelo governo municipal mediante a adesão à municipalização por meio do Convênio nº 010/1997.

É uma escola de grande porte, possui 46 salas de aulas, sala de professores(as), sala de direção, sala de coordenação, sala de secretaria, uma biblioteca, sala de leitura, uma sala de informática com acesso à internet com computadores para uso dos alunos(as), pátio coberto, uma quadra poliesportiva coberta, almoxarifado, refeitório e banheiros. Em seu quadro de funcionários, há 79 docentes lotados, 05 auxiliares/monitores/tradutores de Libras e demais servidores de apoio complementares, totalizando 158 funcionários.

De acordo com dados do INEP, em 2017 essa unidade escolar apresentou um total de 1.973 matrículas distribuídas em 83 turmas nos três turnos de funcionamento - Ensino Fundamental (anos iniciais e finais) e Educação de Jovens e Adultos; e um total de 123 alunos matriculados em tempo integral.

Quadro 1 - IDEB, Meta, Taxas Aprovação Anos Iniciais, Nota Padronizada Prova Brasil, coeficientes Padronizada Língua Portuguesa e Matemática. Anos Iniciais e Anos Finais do Ensino Fundamental da EMEF

\begin{tabular}{|c|c|c|c|c|c|c|}
\cline { 2 - 7 } \multicolumn{1}{c|}{} & \multicolumn{2}{c|}{2013} & \multicolumn{2}{c|}{2015} & \multicolumn{2}{c|}{2017} \\
\cline { 2 - 7 } & $\begin{array}{l}\text { Anos } \\
\text { Iniciais }\end{array}$ & $\begin{array}{l}\text { Anos } \\
\text { Finais }\end{array}$ & $\begin{array}{l}\text { Anos } \\
\text { Iniciais }\end{array}$ & $\begin{array}{l}\text { Anos } \\
\text { Finais }\end{array}$ & $\begin{array}{l}\text { Anos } \\
\text { Iniciais }\end{array}$ & $\begin{array}{l}\text { Anos } \\
\text { Finais }\end{array}$ \\
\hline IDEB & 4,1 & 3,4 & 4,3 & 3,4 & 4,7 & 3,5 \\
\hline Meta & 4,3 & 4,4 & 4,5 & 4,7 & 4,8 & 5,0 \\
\hline $\begin{array}{l}\text { Taxas de Aprovação } \\
\text { Pota Padronizada }\end{array}$ & 0,87 & 0,74 & 0,84 & 0,74 & 0,88 & 0,76 \\
\hline
\end{tabular}

${ }^{5} \mathrm{O}$ processo de municipalização do ensino foi decorrente do amplo processo de descentralização das políticas públicas iniciado na década de 1990 e das reformas educacionais implementadas pelo governo FHC nesse período. Exemplo disso foi o próprio processo de municipalização da educação que ocorreu em todo o País, por força da EC 14/96, que instituiu a implantação do Fundo de Desenvolvimento do Ensino Fundamental e Valorização do Magistério - FUNDEF. Segundo Miléo (2007), a municipalização do ensino fundamental no estado do Pará foi prevista na elaboração do Plano Estadual de Educação (1995-1999) no governo de Almir Gabriel, sendo o primeiro estado no País a implementar o FUNDEF, a partir da proposta intitulada "Municipalização do Ensino Fundamental no Estado do Pará", aprovada por meio da Lei Estadual n". 6.044, de 16 de maio de 1997, apresentada em agosto do mesmo ano pela Secretaria Estadual de Educação - SEDUC. Entre os meses de setembro a dezembro, aderiram à proposta de municipalização 42 municípios, entre eles, o município de Medicilândia. 


\begin{tabular}{|l|c|c|c|c|c|c|}
\hline $\begin{array}{l}\text { Proficiência } \\
\text { Padronizada Língua } \\
\text { portuguesas }\end{array}$ & 4,6 & 4,4 & 5,0 & 4,5 & 5,2 & 4,5 \\
\hline $\begin{array}{l}\text { Proficiência } \\
\text { Padronizada } \\
\text { matemática }\end{array}$ & 4,8 & 4,6 & 5,4 & 4,8 & 5,4 & 4,6 \\
\hline
\end{tabular}

Fonte: MEC/INEP.

De acordo com o Instituto Brasileiro de Geografia e Estatística (IBGE, 2010), a origem do município de Medicilândia está relacionada ao Programa de Integração Nacional (PIN), instituído no ano de 1970 e implantado a partir de 1971, pelo Governo Federal, que tinha como objetivo desenvolver um programa de colonização na Amazônia com a abertura da Rodovia BR 230 - Transamazônica. Em 1984, o município foi distrito do município de Prainha, tendo sido desmembrado e elevado à categoria de município em 6 de maio de 1988, com sede no km 90-faixa, instalado em $1^{\circ}$ de janeiro de 1989.

Figura 1 - Mapa do município de Medicilândia - Pará.

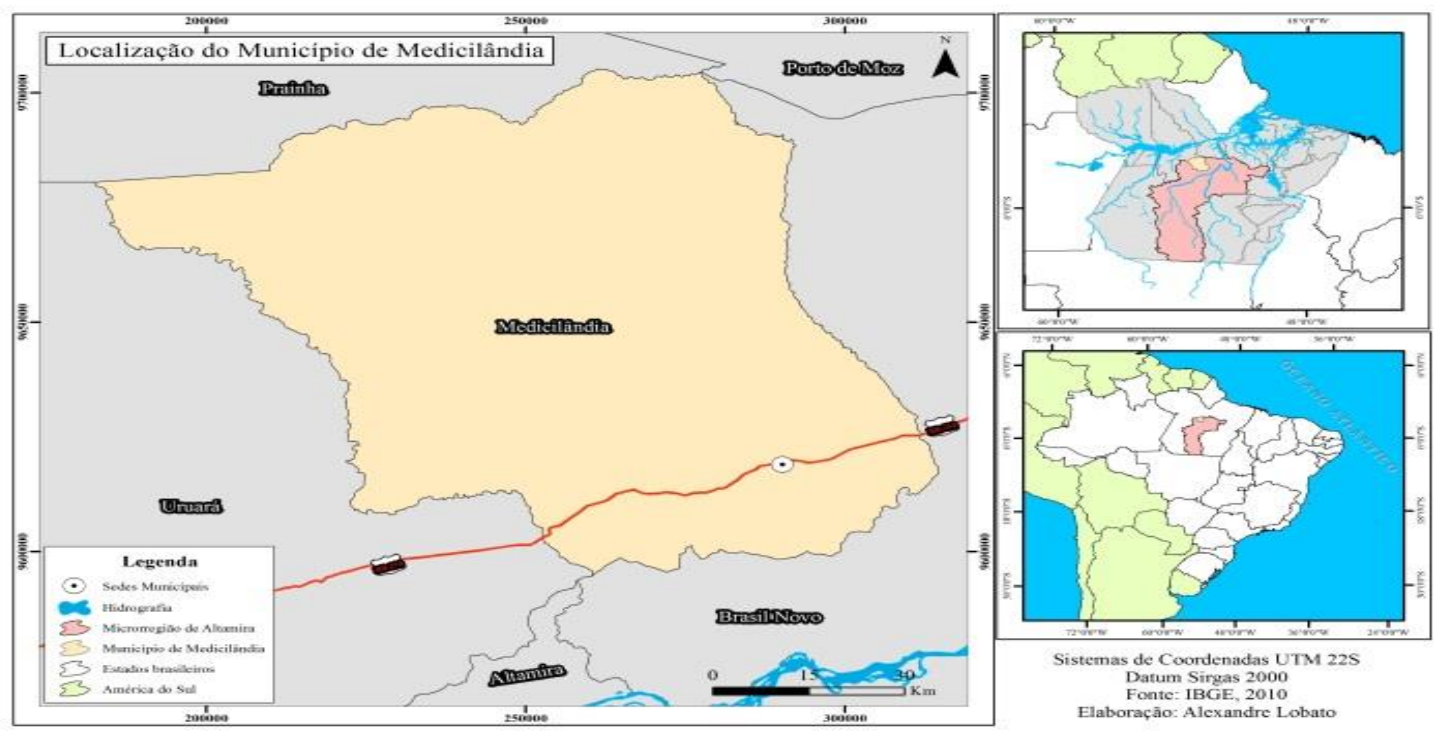

Fonte: elaborada pelos autores.

O município pertencente à Mesorregião do Sudoeste Paraense, microrregião de Altamira, e está localizado às margens da Transamazônica BR 230 sentido Altamira Itaituba; tem seus limites com os municípios de Prainha, Porto de Moz, Brasil Novo e Uruará. Sua população estimada é de 30.726 habitantes. Possui uma área de unidade territorial de $8.272,629 \mathrm{~km}^{2}$, e sua densidade demográfica é 3,3. É considerada a capital nacional do cacau, onde se tem a fábrica de chocolate Cacauway (IBGE, 2017). 
A taxa de escolarização do município (para pessoas de 6 a 14 anos) foi de $94.5 \%$ em 2010, colocando o município na posição 87 de 144 cidades do estado e na posição 5.134 das 5.570 cidades brasileiras. Os dados do IBGE apontam para 4.693 o número de matriculados(as) no Ensino Fundamental, nas 43 escolas públicas municipais existentes. Já a taxa de analfabetismo, em 2010, era de 6,5\%, taxa considerada alta em comparação com a realidade nacional, que era $8,7 \%$ em 2012, porém condizente com a situação da região Norte, que era $28 \%$ (IBGE, 2010).

A unidade escolar, junto com o conselho escolar, administra os seguintes programas federais: Programa Dinheiro Direto na Escola (PDDE), Programa Dinheiro Direto na Escola Educação Integral (PDDE-EI) e o Programa Mais Educação. No ano de 2018 foi contemplada com o Programa instituído pelo Ministério da Educação "Mais Alfabetização", através da Portaria $\mathrm{n}^{\mathrm{o}} 1.144$, de 10 de outubro de 2016, criado com a finalidade de fortalecer e apoiar as escolas no processo de alfabetização dos estudantes do $1^{\circ}$ e $2^{\circ}$ anos do ensino fundamental, que atenderá uma turma de $1^{\circ}$ ano e duas turmas de $2^{\circ}$ ano.

A referida escola participa ainda das avaliações institucionais no decorrer do ano letivo em todos os níveis e esferas, municipal, estadual e federal, que avaliam o desempenho geral da instituição e também dos setores que a compõem, bem como o desempenho dos estudantes; como exemplo temos: Prova Brasil (ARENSC); Provinha Brasil; Avaliação Nacional da Alfabetização (ANA); Avaliação de desempenho funcional (municipal); Olimpíada de matemática das escolas públicas e Avaliação do Matematicando (OBMEP), nível local e municipal.

\section{A gestão democrática via processo de eleição direta ao cargo da direção escolar}

Com perspectivas de seguir as orientações e os princípios da gestão democrática determinados pela Constituição Federal de 1988 e pela Lei de Diretrizes e Bases da Educação (LDB 9.394/96), a Prefeitura Municipal de Medicilândia tem empreendido medidas, a exemplo da Lei Complementar $n^{\circ}$. 01/2015, que dispõe sobre a reformulação do Plano de Cargos, Carreira e Remuneração dos profissionais em Educação Básica do Ensino Público na Rede Municipal em Medicilândia, sua gestão e dá outras providências, onde no Capítulo I, Artigo $1^{\circ}$, Inciso III, estabelece "a participação do servidor na elaboração e execução do Projeto Político Pedagógico da Escola” e no Inciso V “o compromisso com uma escola verdadeiramente cidadão". 
Nesse mesmo documento, na seção XI, Artigo 32, que trata sobre os anexos dessa Lei Complementar, preconiza o PCCR (anexo da Lei) a realização da eleição para a ocupação de cargo de direção e vice-direção, que deverá ser ocupado por professores com habilitação em Pedagogia ou especialização em gestão, e ainda, discrimina as atribuições da gestão escolar e coordenação pedagógica, devendo esta ser ocupada por Pedagogo ou licenciado com especialização específica (MEDICILÂNDIA, 2015).

Nessa municipalidade foi sancionada a Lei Municipal $n^{\circ} .430 / 2015$, que trata da aprovação do Plano Municipal de Educação (PME), em concordância ao disposto no artigo $8^{\circ}$ do Plano Nacional de Educação (PNE), Lei no 13.005/2014. Com isso, uma das diretrizes do PNE foi mantida no Artigo $2^{\circ}$ do PME, que é "VI promoção do princípio da gestão democrática da educação pública;" (MEDICILÂNDIA, 2015). Na meta 19 desse PME está disposto o prazo de um ano após sua aprovação para que seja efetivada a gestão democrática na educação, com critérios técnicos e consulta pública à comunidade escolar no âmbito das unidades escolares públicas, assim como previsto no PNE atual.

Em relação ao processo da eleição para direção escolar, a Resolução nº. 085, de 31 de janeiro de 2011, que aprova o Regimento Escolar e Estrutura Curriculares Unificados para Rede Municipal de Ensino de Medicilândia - PA, Seção II, trata sobre a Direção e ViceDireção serem eleitas pela comunidade escolar.

Essa Resolução citada subsidiou a criação da Lei Complementar nº 01/2015, em relação ao processo eleitoral para gestão escolar, estando expressas as orientações no capítulo II, seção X, Artigo 25, que dispõe: “as funções de direção e vice-direção dos estabelecimentos de ensino do município de Medicilândia deverão ser ocupados por professores eleitos, cabendo ao Poder Executivo, a nomeação do vencedor da eleição". No parágrafo $1^{\circ}$ da referida lei, diz que o processo eleitoral será organizado e efetivado pelo Conselho Escolar, e que para concorrer ao cargo o servidor tem que ser efetivo do quadro da educação, com no mínimo três anos no total e um ano na escola em que for candidato. No $2^{\circ}$ parágrafo, orienta que no ato da inscrição o concorrente deverá apresentar seu projeto pedagógico e plano de trabalho para o período de gestão (MEDICILÂNDIA, 2015).

Quando observamos esses documentos, verificamos que estão em concordância com o estabelecido pela LDB 9394/96, que ao tratar dos profissionais da educação, determina, no seu artigo 67, parágrafo único, que "a experiência docente é pré-requisito para o exercício profissional de quaisquer outras funções de magistério, nos termos das normas de cada sistema de ensino". Outrossim, o Conselho Nacional de Educação, ao normatizar esse dispositivo da LDB, coloca, na Resolução CEB/CNE 03/97, Artigo 3ㅇ, § 1: “A experiência 
docente mínima, pré-requisito para o exercício profissional de quaisquer funções de magistério, que não a de docência, será de 02 (dois) anos e adquirida em qualquer nível ou sistema de ensino público ou privado".

Entretanto, através do "Histórico da Escola Abraham Lincoln" de autoria de Torres (2015), infere-se que as gestões que assumiam a administração escolar eram por indicações realizadas pelos poderes executivos estaduais e municipais, porém, em 2003, inicia-se o processo de eleições diretas para direção e vice-direção, sendo uma conquista que teve a participação das gestoras da época, Professoras Rejane Malveira Vaz (diretora) e Elizabete Catarina Podanoschi e, também, a participação da comunidade escolar (TORRES, 2015).

Em entrevista com o Secretário Municipal de Educação da gestão em que foi criado o processo de eleição para diretor (2001-2004), perguntamos a ele como foi pensado o processo da gestão escolar democrática e qual sua concepção sobre a mesma. Este se posicionou da seguinte forma:

Acreditar que seria uma maneira de organizar o funcionamento da escola pública quanto aos aspectos políticos, administrativos, tecnológicos, culturais, artísticos e pedagógicos, com a finalidade de dar transparência ás ações e atos, possibilitando à comunidade escolar e local, aquisição de conhecimentos, saberes, ideias e sonhos, através de um processo de aprender, inventar, criar, dialogar, construir, transformar e ensinar. Gestão escolar democrática, basicamente, seria a implantação nas unidades escolares de uma dinâmica que garanta processos coletivos de participação $e$ decisão, exigindo mais do que simples mudanças nas estruturas organizacionais, requer mudanças de paradigmas que fundamentam uma proposta educacional baseada no coletivo com foco na qualidade e nas novidades da sociedade quanto ao conhecimento, mudança continua e continuada.

Segundo esse profissional, é necessário problematizar o processo educacional do País, com vistas a superar "[...] a educação de fracasso e de exclusão para uma educação de qualidade, diante da perspectiva de mais participação e controle dos atores da educação". Considera ainda que somente por meio de uma gestão democrática, a escola abre possibilidades para os pais participarem "[...] na definição das propostas pedagógicas da escola de seus filhos, acompanhando o desenvolvimento escolar e avaliando os resultados" (Secretário Municipal de Educação, 2001-2004).

Diante desse relato observamos que o entrevistado apresenta um entendimento sobre a gestão democrática que promove mudanças no cotidiano das práticas escolares e dos paradigmas educacionais excludentes, uma vez que oportuniza envolvimento de diferentes agentes educativos e segmentos nos processos pedagógicos, buscando melhorar a qualidade 
do ensino e o acompanhamento das aprendizagens das estudantes por sua família. Para Bordignon e Gracindo (2006, p. 147), "a gestão transforma metas e objetivos educacionais em ações, dando concretude às direções traçadas pelas políticas”. Consequente, a gestão não pode ser tratada como uma atividade técnica, ao contrário, como um "processo políticoadministrativo contextualizado, através do qual a prática social da educação é organizada, orientada e viabilizada", em comum acordo com a comunidade escolar e local.

\section{Resultados e discussões: as vozes dos sujeitos da pesquisa}

A gestão dita democrática da escola pública precisa transcender a ideia de centralidade na figura do diretor escolar como o único responsável pelos processos decisórios, imagem que sobrecarrega esse profissional de funções administrativas e pedagógicas, tendo em vista aspectos de regulação, monitoramento, controle e avaliação do componente curricular escolar. Nos últimos anos, a gestão escolar tem tido enfoque renovado, especialmente após promulgação da Constituição Federal de 1988, ratificadas pela LDB 9394/96, com um modelo voltado para o papel da direção escolar, com mudanças nas demandas funcionais e nas transformações nos papeis da gestão educacional e escolar.

Assim, as discussões que se inscrevem no campo da gestão escolar, de modo particular aquelas que trazem em si proposições democráticas, tornam necessário ouvir os sujeitos que compõem o espaço escolar, como diretores, professores, alunos, membros do conselho escolar e outras pessoas da comunidade local, como nos diz Libâneo (2008, p. 122), ao se referir à gestão democrático-participativa como um modelo de gestão que "baseia-se na relação orgânica entre direção e a participação dos membros da equipe".

Considerando essa questão no estudo realizado, perguntamos aos nossos entrevistados como concebem a gestão escolar e gestão escolar democrática. Seus relatos evidenciam compreensões que demonstram apropriação do seu significado participativo e partilha de decisões, próxima das apresentadas por Paro (2007).

Para mim, gestão escolar é feita por um conjunto de profissionais da área de educação (professores) para administrar a escola e realizar o trabalho pedagógico e atendimento aos alunos que apresentem problemas de conduta ou aprendizagem e que todos busquem juntos, uma educação de qualidade. Já a gestão democrática, além dessas especificidades vai um pouco mais além, pois envolve as pessoas a quem a educação se destina: pais, alunos, sociedade civil organizada; envolve outros segmentos administrativos como, secretaria de saúde e meio ambiente, dando a oportunidade de participação e sugestão para administrar a escola e dividir responsabilidades tendo seu poder de representatividade através do conselho escolar. (Professora A). 
Compreendo que é o que faz a escola caminhar para o futuro, juntamente como todos os professores, alunos, administrativos, apoio, família e demais envolvidos no processo educativo. Quando todos participam, opinam, desenvolvem seu trabalho com liberdade para mudar o que precisa ser mudado, corrigir, criar, está automaticamente democratizando a gestão escolar. (Professora B).

É uma forma de administrar uma unidade escolar, que visa atender as necessidades dos setores que envolvem essas práticas, tais como: funcionários, estrutura física da escola. Na minha concepção, a gestão escolar democrática deve ser composta pela participação dos vários segmentos da comunidade escolar (pais, professores, estudantes e funcionários), em todos os aspectos da escola. Participando direta e indiretamente nas diferentes etapas de planejamentos, implementação e avaliação. (Presidente do Conselho Escolar).

A gestão escolar deve ser um processo democrático na qual todos os funcionários devem contribuir para um melhor desempenho. (Secretária do Conselho Escolar).

Quanto aos relatos da diretora escolar e da coordenação pedagógica, seus depoimentos caminham no sentido de apontar a gestão democrática como práticas que articulam a vivência democrática pela via da participação dos todos os agentes educativos e da família, visando à melhoria na aprendizagem dos estudantes, o que também repercute no bom desempenho da instituição escolar.

A gestão escolar é um trabalho que visa organizar e articular os trabalhos diários da instituição, com o intuito de melhorar a eficiência do ensino. A gestão democrática escolar é aquela que garante a democracia, a participação de todos os funcionários da instituição e da comunidade em

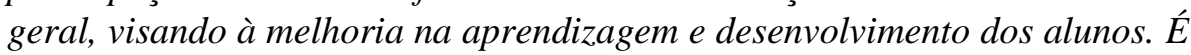
uma forma de administrar uma unidade escolar, que visa atender as necessidades dos setores que envolvem essas práticas, tais como: funcionários, estrutura física da escola. Na minha concepção a gestão escolar democrática deve ser composta pela participação dos vários segmentos da comunidade escolar (pais, professores, estudantes e funcionários), em todos os aspectos da escola. Participando direta ou indiretamente nas diferentes etapas dos planejamentos, implementações $e$ avaliação. (Diretora Escolar, 2016-2018).

A gestão escolar deve ser processo democrático, respeitado e valorizado pela comunidade escolar, ou seja, com a participação dos funcionários da escola, alunos e pais onde todos podem contribuir para o bom desempenho da Unidade de Ensino. A mesma é de fundamental importância para o bom desempenho da escola, onde diretores e coordenadores não medem esforços em torno da instituição. Onde o processo é democrático como seu foco central; deve ter todas as suas decisões orientadas por critérios pedagógicos e devem propor o melhor para o processo ensino $e$ aprendizagem. A gestão escolar se faz necessário para o bom andamento 
das atividades escolares e para que haja ordenamento dentro do espaço educacional. (Coordenação Pedagógica Escolar, 2016-2018).

Em relação ao posicionamento do Secretário Municipal de Educação da gestão atual (2017-2020), este afirmou defender a gestão democrática, por possibilitar as tomadas de decisões coletivas: "Defendo a gestão democrática. Oportunizar todo o corpo docente a tomada de decisões é partilhar resultado do trabalho".

Quando trata sobre a gestão da escola na perspectiva democrática, Libâneo (2008) argumenta que sua validade deve ser defendida e legitimada por todos os envolvidos, visto que favorece a criação de uma cultura organizacional que promove resultados escolares mais qualitativos; além de esta alterar a própria a cultura da escola e as rotinas pedagógicas a partir de ações inclusivas, que respeitem a diversidade existente no espaço escolar:

Por parte dos diretores e coordenadores pedagógicos, é preciso capacidade de liderar e gerir práticas de cooperação em grande grupo, de modo a criar uma cultura organizacional, ou seja, uma mentalidade de organização escolar instituída a partir das percepções, modos de pensar e agir, práticas, próprias da cultura existente entre os integrantes da equipe gestora (LIBÂNEO, 2008, p. 103).

Em relação aos relatos dos estudantes entrevistados, em resposta à pergunta referente à concepção de gestão democrática, estes relataram que a gestão na escola é boa e democrática devido à escola ser organizada, por isso respeitam a direção escolar.

Com base nessas considerações, questionamos aos entrevistados como eles percebem o processo de eleição para direção da escola e se este favorece a efetivação da gestão democrática. Obtivemos posicionamentos que afirmam a convicção que o processo de escolha da direção escolar favorece a participação de todos. O diálogo e o debate entre os candidatos ao cargo e a comunidade escolar e local e, ainda, conhecer suas propostas quanto às ações a serem desenvolvidas no decorrer do mandado, como podemos ver nos trechos abaixo:

Penso que meu posicionamento e opinião são importantes e procuro deixar claro aos possíveis candidatos aquilo que estou esperando, pois costumo cobrar as promessas de campanha e estudar cuidadosamente o plano de gestão que apresentam. (Professora $\mathrm{C}$ ).

Penso que é uma maneira maravilhosa de trazer os interessados no processo educativo para a participação efetiva na escola a resolver os muitos problemas que possui. É bem melhor que um diretor nomeado pela gestão municipal com o poder centralizado. Sim, ele já se constitui um processo de democratização de gestão, mas esse processo será democrático de fato quando houver uma gestão democrática que consiga colocar o aluno no centro do processo de ensino. A escola já consegue às vezes, fazer isso, mas não se constitui uma rotina, são eventos esporádicos e o Brasil inteiro 
precisa buscar caminhos nesse sentido em todas as esferas do ensino, até mesmo no ensino superior. (Professora D).

O processo de eleição para a direção da escola é um ato democrático muito importante, pois os atores envolvidos no processo ensino aprendizagem têm o direito de votar e ser votado, ou seja, participa e interage diretamente em todo o processo político pedagógico, filosófico, etc. (Coordenadora Pedagógica).

Percebo-me como uma pessoa que faz a diferença, pelo fato de ter minhas próprias escolhas. (Aluna do $9^{\circ}$ ano).

Paro (2005), quando discute a participação da comunidade escolar e local na gestão da educação, situa que a escola precisa ser um espaço que envolva os seus usuários nos processos decisórios por meio da veiculação de informações sobre o funcionamento e os resultados escolares, considerando esta como um dos elementos essenciais para fomentar os processos participativos, pois

É por meio da informação que os pais e os demais membros da comunidade podem pôr-se a par de seus direitos e deveres para com a instituição escolar, bem como tomar conhecimento dos fatos e relações que se dão no interior do estabelecimento de ensino e que dizem respeito a seus interesses enquanto usuários do mesmo (PARO, 2005, p. 192).

Identifica-se que, na visão do autor, o conceito de participação representa ponto central quando pensamos na democratização das escolas. Para ele, a participação é um canal que permite à instituição escolar e aos envolvidos no ato educativo se instrumentalizarem para definir os objetivos pedagógicos e administrativos, a exemplo da organização da seleção dos diretores, na escolha dos conselheiros que comporão o conselho escolar, constituído tanto por representantes da comunidade escolar (diretores, vice-diretores, professores, alunos e funcionários), como as pessoas da comunidade local (pais de alunos, movimentos populares, associações de moradores, clubes de mães, grupos culturais), tornando esses sujeitos sociais co-responsáveis pela gestão (PARO, 2007).

Quando perguntamos aos entrevistados sobre como se dá a organização do processo eleitoral na escola, a Secretária do Conselho Escolar relatou que deve ser organizado de forma participativa e precisa envolver toda a comunidade escolar, mas que ainda não participou de nenhuma eleição: "Estou atuando há 08 meses no conselho e ainda não participei de nenhum processo eleitoral". Um estudante do $9^{\circ}$ disse que seu voto "[...] é para aquela pessoa que eu acho que dá conta de assumir seu cargo, também por enquanto está tudo bem. Significa que é uma troca de diretores". 
Sobre essa questão, a Presidente do Conselho Escolar relatou que participa da eleição a partir de seu envolvimento como cidadã a partir de um voto consciente, com a perspectiva de buscar alternativas que colaborem "para o desenvolvimento pedagógico e administrativo da escola. Percebo também que através da eleição há uma descentralização de poder, prevalecendo a vontade da comunidade escolar, pois é uma escolha feita através do voto direto”. A direção escolar (2016-2018) explicou que este se dá da seguinte forma:

O processo eleitoral é organizado e efetivado pelo conselho escolar. Para participar desse processo a fim de concorrer ao cargo de gestor escolar, no ato da sua inscrição o professor deverá apresentar a sua proposta pedagógica, plano de trabalho para execução do seu mandato; deverá ser do quadro efetivo do município e estar lotado na educação por um período de três anos e no mínimo um ano na unidade escolar. Precisa ser licenciado em Pedagogia ou Licenciado em outra área, e ter Especialização em Gestão Escolar. Observar os planos apresentados pelos candidatos, votar e ser votado entre outros.

Em reposta a essa questão, o Secretário Municipal de Educação da gestão atual (20172020), destacou que se trata de momento democrático e precisa ser vivenciado por toda a comunidade, que se torna responsável pela decisão de qual gestor querem para a unidade de ensino. Informou-nos ainda que participa como agente que mobiliza o processo eletivo, ficando a organização sob a incumbência “[...] de uma comissão eleitoral instituída pelo próprio conselho escolar. A participação ela ocorre não só como agente que irá votar, mas se dá através das discussões e análise do perfil do candidato que estará pleiteando a vaga. Está inserido do debate político". Quanto ao Secretário Municipal de Educação do período 20012004, este informou que ao ser instalado o processo de eleição, a intenção foi fazer com a comunidade se envolvesse com a escola e participasse da elaboração da proposta pedagógica:

Expresso comentário sobre a implantação deste processo na EMEF Abraham Lincoln, quando era Secretário Municipal de Educação do município, tivemos a coragem de quebrar regras e normas que dominavam a situação, com indicação direta, puramente política, dos diretores. Ao implantarmos a eleição direta, envolvemos o alunado, pais, corpo docente e discente da escola, com total liberdade de expressão e campanha eleitoral. Por ser novidade houve grande repercussão e aceitação do processo, após a eleição o grande desafio foi de organizar, disciplinar e executar a gestão, graças ao alto grau de profissionalismo e compromisso dos eleitos, pode dizer que a coisa andou e escola cresceu muito, passando a priorizar, realmente o aluno. Por acreditar que nenhum país vai alcançar o seu desenvolvimento, em todos os aspectos, sem que haja um investimento, como prioridade, na Educação, somente através da formação do cidadão teremos uma sociedade consciente e forte o suficiente para traçar o seu rumo, portanto a participação no processo de gestão escolar deveria ser uma meta imperiosa e compromisso dos governantes. 
Nessa perspectiva, percebemos que a eleição direta para a escolha da direção escolar se constitui em mecanismo importantíssimo na efetivação da gestão democrática, a qual precisa se colocar como um de compartilhamento de tomadas de decisões coletivas a partir de debates com a participação da maioria, segundo (LÜCK, 2009). Assim, a eleição para o cargo de direção escolar deve se constituir como um mecanismo não de delegação ou indicação de um profissional a um cargo burocrático, mas como via para o fortalecimento da participação e autonomia da escola na escolha das práticas escolares; em sua concepção, o papel do diretor escolar é "Permitir um diálogo aberto com capacidade de ouvir e compreender as questões de modo contínuo". Possibilitar oportunidades a todos a fim de compartilhar responsabilidades. Ter atitudes e expressões de liderança e não de chefia. Exercício contínuo do diálogo aberto e da capacidade de ouvir (LÜCK, 2009, p. 75).

Todavia, Paro (2010) esclarece que a vivência democrática somente pode ocorrer no cotidiano escolar se o gestor tiver o entendimento de que ele é um articulador de ideias e mediador de ações e decisões coletivas no contexto educacional, dando liberdade aos demais sujeitos se posicionarem diante das questões que estão sendo discutidas. Ressalta ainda que a eleição direta não consegue, por si só, resolver todo o problema da escola, pois demanda a participação de todos nas tomadas de decisão sobre as diferentes dimensões - política, pedagógica e financeira - da gestão escolar.

A eleição de diretores não pode, todavia, ser tomada como uma panaceia que resolverá todos os problemas da escola e muito menos, em particular, os de natureza política. Esta, aliás, tem sido a alegação mais frequente dos que resistem à eleição como alternativa para a escolha do diretor, ou seja, descarta-se a eleição porque 'não é possível atribuir a existência da democracia a apenas uma variável, seja ela o concurso, os cursos, ou, menos ainda, a eleição' (PARO, 2010, p. 28-29).

Com tudo isso, se faz necessário que esse processo eleitoral para diretores seja fortalecido por meio de políticas sociais mais abrangentes, que poderão formar politicamente os sujeitos inseridos no contexto da gestão da unidade escolar.

\section{Considerações finais}

Para finalizar, nossos resultados demonstraram que nossos entrevistados possuem certa compreensão sobre o processo eleitoral direto para escolhas dos dirigentes escolares, e que esse mecanismo influencia significativamente para que ocorra uma gestão democrática escolar, uma vez que os sujeitos envolvidos demostraram conhecimento sobre seu papel 
participativo no cotidiano da comunidade escolar e frequentemente participam da gestão escolar, compartilhada através dos conselhos, reuniões de pais e mestres, construção do PPP, reuniões e/ou oficinas sobre a organização do trabalho pedagógico. No que se refere à legislação municipal (Leis, Resoluções e PME), foi possível observar que as mesmas estão em consonância com o que expressa nossa LDB e nossa Constituição Federal de 1988, com dispositivos legais definidos, delineados, bem elaborados e com sua base alicerçada na organização do trabalho pedagógico macro através da Semed e micro por meio da gestão da unidade escolar.

\section{REFERÊNCIAS}

AZEVEDO, Janete Maria Lins de. Notas sobre a análise da gestão da educação e da qualidade do ensino no contexto das políticas educativas. Revista Brasileira de Política e Administração da Educação, v. 27, n. 3, set./dez. 2011.

AZEVEDO, Janete Maria Lins de. Programas federais para a educação básica: continuidade e mudanças. Revista Brasileira de Política e Administração da Educação, v. 25, 2009.

BRASIL. Constituição (1988). Constituição da República Federativa do Brasil. Brasília, DF: Senado, 1988.

BRASIL, Lei n. 9.394, de 20 de dezembro de 1996. Lei de Diretrizes e Bases da Educação Nacional. Diário Oficial [da] República Federativa do Brasil, Brasília, DF, v. 143, n. 248, 23 dez. 1996.

BRASIL, Lei n. 13.005/2014. Plano Nacional de Educação (PNE - 2014/2024). Diário Oficial [da] República Federativa do Brasil, Brasília, DF: Senado, 2014.

CURY, J. Gestão democrática da educação pública. In: Gestão democrática da educação. Brasília, DF: MEC, p. 14-19, out. 2005. (Boletim, 19).

CURY, J. Gestão democrática da educação em tempos de contradição. Disponível em: www.anpae.org.br/congressos/antigos/simpósio. Acesso em: 20 set. 2012.

DOURADO, Luiz Fernandes. Políticas e gestão da educação básica no Brasil: limites e perspectivas. Educação e Sociedade. Campinas, v. 28, n. 100 esp., p. 921-946, out. 2007.

GADOTTI, M; ROMÃO, J. E. Autonomia da escola: princípios e propostas. São Paulo: Cortez Editora: IPF, 2004.

GIL, A. C. Como elaborar projetos de pesquisa. 4. ed. São Paulo: Atlas, 2009.

IBGE. Dados gerais do município. Disponível em:

https://cidades.ibge.gov.br/painel/painel.php?lang=\&codmun=150445\&search=para|medicila ndia|infograficos:-dados-gerais-do-municipio. Acesso em: 24 out. 2017. 
INEP. Censo escolar. Disponível em: http://matricula.educacenso.inep.gov.br/controller.php. Acesso em: 18 out. 2017.

INEP. Ideb escolar. Disponível em:

http://idebescola.inep.gov.br/ideb/escola/dadosEscola/15106829. Acesso em: 18 out. 2017.

JESUS, Tércio Rios de. Gestão para a qualidade da educação e da escola. Gestão educacional e qualidade social da educação / Organizadora Ana Maria de Carvalho Luz; autores, Adélia Luiza Portela... [et al] -Salvador: ISP/UFBA, 2007.

LIBÂNEO, J. C. Educação escolar: políticas, estruturas e organização. São Paulo, SP: Cortez, 2012.

LIMA, L. C. A escola como organização educativa: uma abordagem sociológica. São Paulo: Cortez, 2001.

LUCK, H. Concepções e processos democráticos de gestão educacional. Série: Cadernos de Gestão. Petrópolis, RJ: Vozes, 2008.

LÜCK, Heloísa. Dimensões de gestão escolar e suas competências. Curitiba: Editora Positivo, 2009.

LUZ, A. M. C. Gestão educacional e qualidade social da educação / Organizadora Ana Maria de Carvalho Luz; autores, Adélia Luiza Portela... [et al]. Salvador: ISP/ UFBA, 2007.

MEC. Plano Nacional de Educação 2014- 2024. Disponível em:

http://pne.mec.gov.br/images/pdf/pne_conhecendo_20_metas.pdf. Acesso em: 10 out. 2017.

MEDICILÂNDIA. Leis Municipais. Disponível em:

http://www.medicilandia.pa.leg.br/institucional/historia. Acesso em: 24 out. 2017.

MILÉO, Irlanda do Socorro de Oliveira. Poder local e a gestão da educação municipal no contexto de Altamira-Pará. Orientadora: Ney Cristina Monteiro de Oliveira. 2007. 265 f. Dissertação (Mestrado) - Universidade Federal do Pará, Centro de Educação, Belém, 2007. Programa de Pós-Graduação em Educação.

PARO, V. H. Administração escolar: introdução crítica. 16. ed. São Paulo: Cortez, 2010.

PARO, V. H. Eleição de diretores: a escola pública experimenta a democracia.2. ed.

Campinas: Papirus, 2003.

SAVIANI, D. Sistema Nacional de Educação e Plano Nacional de Educação. Campinas, SP: Autores Associados, 2014.

TORRES, M.A.L. Histórico da Escola Abraham Lincoln. Acervo da Escola, Medicilândia, out. 2015. 
VIEIRA, S. L. Política(s) e Gestão da Educação Básica: revisitando conceitos simples. RBPAE - Revista Brasileira de Política e Administração da Educação, v. 23, n. 1, p. 53 69, jan./abr. 2007.

\section{Como referenciar este artigo}

BANDEIRA, Marconde Ávila; MONTEIRO OLIVEIRA, Ney Cristina; MILÉO, Irlanda do Socorro de Oliveira. A eleição direta de diretor escolar: desafios na gestão democrática no município de Medicilândia - Pará. Revista on line de Política e Gestão Educacional, Araraquara, v. 24, n. 2, p. 448-477, maio/ago. 2020. e-ISSN: 1519-9029. DOI: https://doi.org/10.22633/rpge.v24i2.13609

Submetido em: 10/02/2020

Revisões requeridas: $28 / 02 / 2020$

Aprovado em: 28/03/2020

Publicado em: 09/04/2020 